\title{
Effects of preoperative pelvic irradiation on colonic anastomosis healing. An experimental study in rats ${ }^{1}$
}

\author{
Efeito da radioterapia pélvica pré-operatória na cicatrização de anastomoses \\ colônicas. Estudo experimental em ratos
}

\author{
Alexandre Franca ${ }^{\mathrm{I}}$, Fernando Silva Ramalho", Leandra Naira Zambelli Ramalho" ${ }^{\mathrm{II}}$, José Joaquim \\ Ribeiro da Rocha ${ }^{\mathrm{IV}}$, Omar Féres ${ }^{\mathrm{V}}$
}

I Fellow Master degree, Division of Coloproctology, Department of Surgery and Anatomy, Ribeirão Preto Faculty of Medicine, University of São Paulo, Brazil.

II PhD, Professor, Department of Surgery and Anatomy, Ribeirão Preto Faculty of Medicine, University of São Paulo, Brazil.

${ }^{\text {III }}$ PhD, Professor, Department of Pathology, Ribeirão Preto Faculty of Medicine, University of São Paulo, Brazil.

${ }^{\text {IV }} \mathrm{PhD}$, Professor, Division of Coloproctology, Department of Surgery and Anatomy, Ribeirão Preto Faculty of Medicine, University of São Paulo, Brazil.

v PhD, Professor, Division of Coloproctology, Department of Surgery and Anatomy, Ribeirão Preto Faculty of Medicine, University of São Paulo, Brazil.

\begin{abstract}
Purpose: Colorectal anastomosis is a constant worry-issue among surgeons because of high rates of complications, specially the dehiscence. The preoperative irradiation on cancer surgeries might interfere in the healing process, leading to an unfavorable outcome. Methods: In the present study, two groups of rats were irradiated previously to a colorectal anastomosis surgery, with intervals of 4 and 8 weeks between the procedures. Seven days after the surgery, healing process was evaluated for dehiscence presence and histologic inflammatory characteristics. Also, levels of hydroxyproline, metalloproteinases and vascular endothelial growth factor were measured. Results: Our results showed a higher incidence of dehiscences on the animals submitted to irradiation, compared to controls, with a reduced inflammatory activity in the healing tissue. Discussion: Comparing both irradiated groups, those irradiated 8 weeks before surgery showed higher levels of hydroxyproline and metalloproteinases, indicating higher efficiency of the healing process. In conclusion, preoperative irradiation interferes with intestinal anastomosis healing and a larger time interval between both procedures is safer in terms of the healing quality.
\end{abstract}

Key words: Colorectal Anastomosis. Preoperative Irradiation. Healing. Dehiscences. Irradiation. Colorectal Cancer.

\section{RESUMO}

Introdução: As anastomoses colorretais são motivos constante de preocupação por parte dos cirurgiões, em virtude do alto índice de complicações, principalmente as deiscências. O uso da radioterapia previamente à cirurgia, nos casos de doença neoplásica, pode interferir no processo cicatricial das anastomoses, e levar a uma evolução desfavorável. Métodos: Os autores estudaram dois grupos de ratos, submetidos a radioterapia e à confecção de uma anastomose no cólon, com intervalo de 04 e de 08 semanas entre os dois procedimentos, comparando com um grupo controle. Após 07 dias da cirurgia, estudaram-se vários aspectos do processo cicatricial: presença de deiscência, características inflamatórias do tecido, dosagem de hidroxiprolina, de mateloproteinase e de VEGF. Resultados: Os autores detectaram maior índice de deiscência nos animais submetidos à radioterapia, com prejuízo da atividade inflamatória característica de um tecido em cicatrização. Discussão: Dentre os dois grupos irradiados, aquele com intervalo de oito semanas entre a radioterapia e a confecção da anastomose teve dosagem mais alta de hidroxiprolina e metaloproteinase, demonstrando maior eficiência do processo cicatricial. Conclusão: A radioterapia prévia interfere no processo de cicatrização das anastomoses intestinais, e que um maior intervalo de tempo entre os dois procedimentos é melhor para garantia de uma cicatrização satisfatória.

Descritores: Anastomose Colorretal. Cicatrização. Deiscências. Radioterapia. Câncer Colorretal.

1. Study performed in the Division of Coloproctology of the Department of Surgery and Anatomy of Ribeirão Preto Faculty of Medicine, University of São Paulo, Brazil. 


\section{Introduction}

Colorectal anastomosis is a constant worry-issue among surgeons. Several studies have demonstrated that high rates of postoperative morbidity and mortality in colorectal surgeries are associated to anastomotic leaks. ${ }^{1-5}$ Colorectal anastomotic dehiscences area also significantly related to increased hospital stay and elevated treatment costs $^{6,7}$ as also with local recurrence of the disease in patients with rectal cancer. ${ }^{8,9}$

The occurrence of intestinal anastomoses complications is associated to several factors like technical, local and systemic, which will interfere with the healing process. It is well known that a safe anastomosis has to be performed with no suture tension, insurance of good perfusion of the bowel ends, pervious lumen, hermetic closure, meticulous hemostasis, absence of distal obstruction and anatomic approximation of the bowel ends..$^{2,10,11}$ The systemic factor that might interfere with the anastomosis are ageing, ${ }^{5,11}$ malnutrition ${ }^{3,7}$ anemia, ${ }^{12,13}$ necessity of blood transfusion, ${ }^{6,14}$ intraoperative hypotension, ${ }^{15-17}$ anastomosis performed under emergency procedure ${ }^{2,18}$ and pharmacological agents. ${ }^{19-21}$ Local factors are significantly important such as infection, ${ }^{6,11,15}$ intra or extra-peritoneal localization of the anastomosis, ${ }^{4,22-25}$ preoperative bowel preparation ${ }^{26,27}$ and diverting stomas., ${ }^{5,12}$

Preoperative radiotherapy is being successfully used as and adjuvant in rectal cancer therapy and is mentioned as a very important local factor that contributes to intestinal anastomosis dehiscences. ${ }^{28,29}$ These complications are still a controversial issue and several studies are being conducted inn order to evaluate anastomosis healing under a irradiated tissue. ${ }^{14,30-34}$ Many attempts are being made in order to define the best time interval between irradiation and tumor resection: early after irradiation ( 2 to 4 weeks) or later ( 6 to 8 weeks)..$^{35,36}$

The present experimental study aimed to investigate the effects of preoperative pelvic irradiation in the colonic anastomoses healing, in order to determine the best time interval between irradiation and surgery.

\section{Methods}

Forty-five adult male Wistar rats (body weight = 280-346g), from the animal care facility of the School of Medicine of Ribeirão Preto, University of São Paulo, were divided into 3 experimental groups. Under anesthesia, all animals were submitted to a laparotomy and anastomosis of the large bowel. Group I rats, which were submitted just to the laparotomy were used as controls. Group II rats were submitted to pelvic irradiation 4 weeks before the anastomosis and Group III rats were submitted to pelvic irradiation 8 weeks before surgical procedure. The animals were maintained in the experimental surgery animal care facility and received tap water and rat chow ad libitum throughout the experiments.

Pelvic irradiation was performed at the Radiotherapy Service in the School of Medicine of Ribeirão Preto Hospital and Clinics, University of São Paulo. A
Gammatron S-50 Siemens font was used, with a $1.025 \mathrm{MeV}$ average energy and collimation to a frontal beam of $3 \times 3 \mathrm{~cm}$, focus distance of $80 \mathrm{~cm}$ and build-up of $0.5 \mathrm{~cm}$. Radiation dose was $4500 \mathrm{cGy}$, divided into $180 \mathrm{cGy} /$ day, for 5 days a week, for 5 consecutive weeks.

Seven days pos surgery, the animals were killed and an inventory of the abdominal cavity was done, in order to investigate gross aspects of the anastomoses (adhesions, peritonitis, dehiscences). Afterward, approximately $2.0 \mathrm{~cm}$ of the large bowel, containing the anastomosis, was removed, opened and revised. After rinsing in cold physiological saline solution $(\mathrm{NaCl} 0.9 \%)$, the fragments were frozen in $-20^{\circ} \mathrm{C}$ for further hydroxyproline dosage. The procedures used were those described by Stegemann and Stalder (1967), ${ }^{37}$ modified by Medugorac (1980), ${ }^{38}$ with no drying on vacuum oven. For the histological analysis, bowel segments were stained with hematoxylin-eosin and Masson trichromic. The observation was done under the light microscope with a blind observer to group identity. Healing conditions were observed and described for the following characteristics: fibrin-leukocyte crust, focal necrosis, fibrin deposit, eosinophilic exudate, local edema, lymphatic dilatation, vascular congestion, local hemorrhage, neutrophilic exudate, mucosal regeneration, macrophagic infiltrate, granulomas, vascular neoformation, fibroblastic proliferation and fibrosis. Each of these features was classified in scores as follows: (0) absent, (+) light, (++) moderate, $(+++)$ intense.

Anastomotic segments were also submitted to a immunohistochemistry study for metalloproteinase I (MMP1), metalloproteinase I inhibitor (IMMP1) and vascular endothelial growth factor (VEGF) and a semiquantitative analysis of the presence of these substances was performed.

All data analyzed were submitted to a statistical analysis. To macroscopic data comparisons the Fisher exact test was used. For hydroxyproline dosage, and immunohistochemical analysis of the MMP1, IMMP1 and VEGF, the Kruskal-Wallis non parametric test was used. For qualitative data obtained on the histological evaluation, the ridit-scores quantification was used ${ }^{39}$. Differences were considered significant when $\mathrm{p}<0.05$.

\section{Results}

Macroscopic evaluation showed that adhesions occurred in all animals, of all three groups but anastomosis dehiscences were seen only on animals submitted to irradiation. No generalized peritonitis was found in any of the irradiated animals. No statistical differences were found between groups.

Hydroxyproline dosage was between 86 and 133 $\mu \mathrm{g} / 100 \mathrm{mg}$ with average value of $113.50 \mu \mathrm{g} / 100 \mathrm{mg}$ in the control animals (Group I). In group II animals, the values were between 72 and $157 \mu \mathrm{g} / 100 \mathrm{mg}$, with an average of $118.50 \mu \mathrm{g} / 100 \mathrm{mg}$. In group III animals, values were between 97 and $182 \mu \mathrm{g} / \mathrm{mg}$, with an average of $144.00 \mu \mathrm{g} / 100 \mathrm{mg}$. A statistical difference was observed between groups I and III and also between groups II and III (Figure 1). 


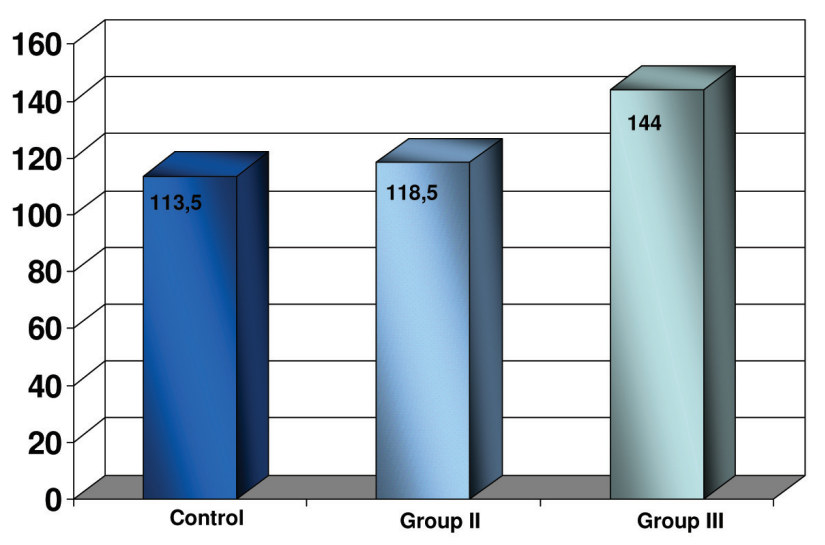

FIGURE 1 - Hydroxyproline dosage
Results of the histological evaluations of the anastomosis are shown on Figure 2a-f. A significant difference was found for edema between groups I and II, for congestion between groups II and III, for the fibrinleukocyte crust between groups I and III, for the eosinophilic infiltrate between groups I and III, for the macrophage infiltrate between groups I and II and for local hemorrhage between groups II and III. Vascular congestion was more intense on group III, being significantly different from groups I and II. Local hemorrhage was a frequent finding on group III animals, also with more intense grade in comparison to groups I and II. The eosinophilic infiltrate was highly present on group I and significantly reduce on group III. The same observation was made for the macrophage infiltrate.
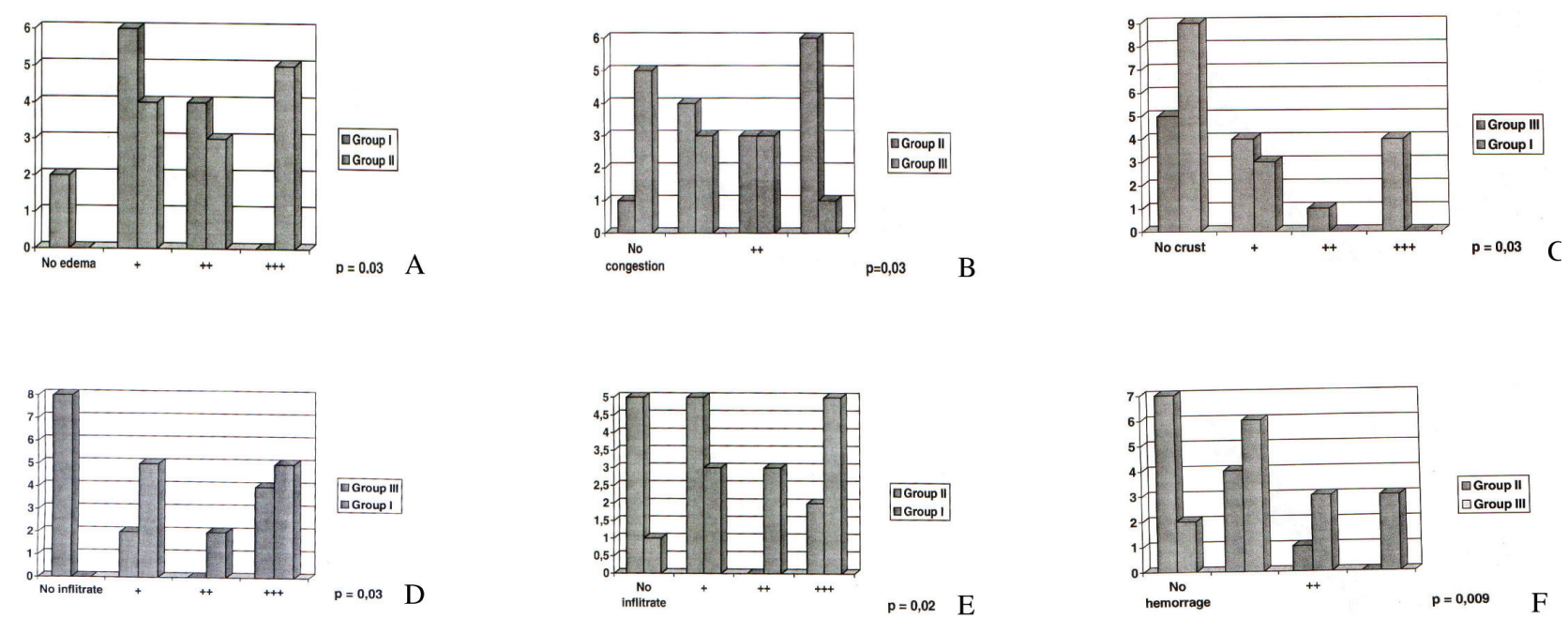

FIGURE 2 - $\quad$ Histological evaluation for A) edema, between groups I (control) and II; B) congestion, between groups II and III; C) fibrin-leukocyte crust, between groups I and III; D) eosinophilic infiltrate, between groups I and III. E) macrophage infiltrate, between groups I and II; F) local hemorrage, between groups II and III.

Data of the immunohistochemistry evaluation is shown on Figure 3. There was a significant difference on the MMP1 between groups I and III, with no difference between groups I and II. Also, no differences were observed between groups for the IMMP1 and VEGF.
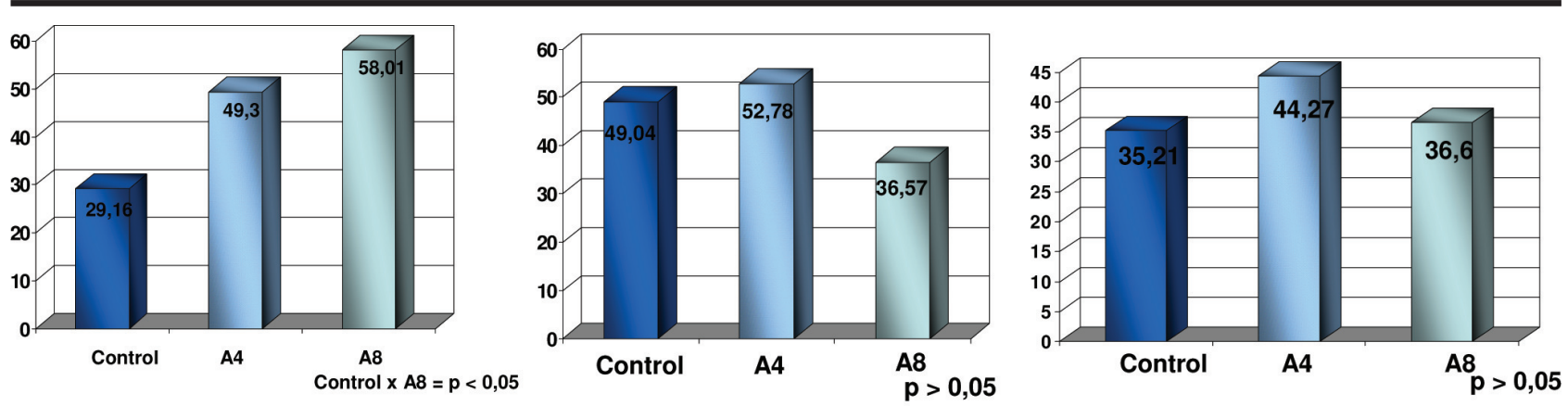

FIGURE 3 - Comparison of the groups studied regarding marker of metalloproteinase1, metalloproteinase 1 inhibitor and vascular endothelial growth factor. 


\section{Discussion}

The intestinal anastomosis dehiscence is a consequence of a healing process failure. Since the healing stages and factors involved in each of them are well known, recent studies try to correlate dehiscences risk factors with a determined healing stage in order to investigate which factor would be responsible for the healing failure. It is known, for example, that there is an over expression of collagenase in peritonitis, which would may cause a failure in repairing the suture line. ${ }^{40-42}$

With the aid of radiotherapy, rectum cancer treatment has been showing improvement of life quality, better postoperative outcome and reduced rates of morbidity. When radiotherapy is done on the preoperative period, it also allows surgeons to perform more conservative procedures with sphincter function preservation. ${ }^{28}$ Despite all these advantages, preoperative radiotherapy influences negatively on the anastomoses healing.

Our study showed that, despite the absence of statistical differences, only irradiated animals presented anastomotic dehiscences, suggesting the negative influence of the radiotherapy on the anastomosis healing. Other literature reports presented similar results, with also the presence of mucosal erosions after the irradiation. $3^{4}$

In the present study, some of the inflammatory/ healing stages showed significant differences between groups. Edema was more intense on rats irradiated 4 weeks compared to controls and even more intense on rats irradiated 8 weeks, compared to both groups. The same observation was made for the focal hemorrhage data. These phenomena are associated with the vascularization of the irradiated area and the differences observed on group III are in accordance to the irradiation effects on blood vessels, which include dilatation, wall rupture and capillary loss. The main consequences of this is the reduction of the microvascular bed and local ischemia, ${ }^{43-44}$ with impaired healing. On our results, no differences between groups were found on factors related to angiogenesis, which was not expected since the new vascular bed should be impaired due to irradiation, as are other factors related to it. Either the eosinophilic as the macrophage infiltrates were larger on control group. In this way, the inflammatory process was reduced on the irradiated groups. This lack of cellular response and inflammation is characteristic of the later tissue lesion caused by irradiation. ${ }^{45}$ The healing region shows a minimum number of granulocytes, lymphocytes and macrophages, which is associated with disorganization on the inflammatory process stages of healing. The fibrinleukocyte crust is part of the surface of the destroyed mucosa and it is present at the beginning of the healing process. Afterwards, it gives place to the regenerative epithelia underneath it. The presence of this crust was more evident on group III compared to controls, which also suggests a healing impairment on the irradiated group.

Collagen quantification is a biochemical method for evaluation of anastomoses healing. Fibroblasts use methionine and cysteine amino acids to synthesize mucopolysacarides and collagen. Collagen present on the extracellular compartment is considered as responsible for the mechanic resistance of the scar. ${ }^{46}$ The proline and lysine hydroxylation, which is fundamental for collagen synthesis, occurs in the presence of oxygen, ascorbic acid, ionic iron, ketoglutarate and zinc. ${ }^{47}$ With proline biochemical modification, collagen adds to its chain the hydroxyproline, which forms approximately one third of its amino acids. ${ }^{48,49}$ Measuring hydroxyproline is an indirect way of measuring collagen and this dosage is being useful on the biochemical evaluation of healing processes. In the present study, the $7^{\text {th }}$ day postoperative was chosen because it represents the healing proliferative stage ( 3 to 14 days), when the fibroplasia process is dominant. ${ }^{50}$

In our results, hydroxyproline dosage was significantly higher on group III, which suggests that 8 weeks would be the best time interval for the colonic anastomosis after irradiation. Other studies performed in similar conditions show controversial results. Kuzu et al. $(1998)^{51}$ found a significant reduction in the anastomosis tension on the $3^{\text {rd }}$ and $7^{\text {th }}$ postoperative time, a reduced mieloperoxidase (a marker of leukocyte local accumulation) activity and a reduction on the hydroxyproline content on the colonic anastomosis on rats submitted to irradiation. Biert et al. (1997) ${ }^{52}$ did not show significant differences on the hydroxyproline content on the anastomosis. De Meerleer et al. (1999) ${ }^{53}$ also in an experimental study with rats, studying the anastomosis rupture-pressure, showed that the anastomoses were not affected when only one of the extremities was irradiated. Studies on anastomosis performed after radiotherapy or chemotherapy also have not demonstrated significant differences between groups, using the same evaluation protocol..$^{33}$ Ceelen et al. ${ }^{32}$ did not show differences on the dehiscence frequency, hydroxyproline content and rupture-pressure on rats submitted to preoperative irradiation.

Collagen is a dynamic protein, being in constant balance between break and synthesis and collagenase is the most important metalloproteinase involved in the intestinal anastomoses healing. Immunohistochemistry techniques detect the presence of this metalloproteinase during the first 24 hours after the anastomosis. ${ }^{54}$ Its activity is very intense on the first days, interfering with the collagen synthesis to allow macrophages, neutrophiles and fibroblast reach the region. With healing evolution, its activity is progressively reduced, so that new extracellular matrix (mainly collagen) is generated and the mechanic resistance of the scar increases. Due to the intense participation of the metalloproteinase during the healing process, its quantification by immunohistochemistry is useful in the evaluation of the anastomosis healing. A higher metalloproteinase activity shown on group III compared to controls, found in this study has to be interpreted cautiously. The collagen metabolism is due to a continuous break and synthesis of this protein. In physiological states, there is a balance between both activities and a slow protein renewal. During inflammation and healing the collagen is destroyed first and only on later stages there will be new molecules deposit. The metalloproteinase activity will increase on initial stages, breaking the molecules, and will be reduced on later stages, allowing the tissue 
reconstruction and the effective collagen deposit on the scar region. In this way, our results show that there was a higher metalloproteinase activity on group III, which might suggest impairment on the anastomosis healing. Nevertheless, it is only part of all events that are being analyzed. The main goal of the healing process is to establish a new balance between break and synthesis, forming a new and resistant connective tissue. In this way, a higher activity of a collagenase in this phase might represent a balance action, depending on the amount of collagen to be remodeled. We consider that this larger amount of collagen is in balance with the hydroxyproline concentration, which was also higher on group III. These finds put together suggest a balance between break and synthesis, indicating that the 8 -week interval between irradiation and surgery was the most appropriate to perform the intestinal anastomosis. The evaluation of the metalloproteinase inhibitor activity did not show differences between groups, suggesting that collagen lyses was uniform between them.

No differences were found for the VGEF between groups on the anastomotic area. This was not expected since the endothelial cells are radiosensitive and the irradiation would impair the angiogenesis. The VGEF acts directly on the endothelial cells. The angiogenesis is a complex cellular phenomenon that leads to a capillary new formation and grow, from existing endothelial cells. ${ }^{55}$ Macrophages, monocytes, lymphocytes, fibroblasts and also endothelial cells themselves might interfere on the angiogenesis process by releasing substances which would inhibit the angiogenesis process. Local hypoxia seems to be the most important stimulus to angiogenesis. ${ }^{56,57}$

Several studies that evaluated the preoperative irradiation effects on anastomosis healing show different methodologies, specially on the total dose of irradiation, time-interval between irradiation and surgery and postoperative time to evaluate the anastomotic region. ${ }^{30,32-}$ 34,51,53,58 This methodological variety might explain differences between the results obtained for different authors.

\section{Conclusions}

In conclusion, our results suggest that, in this experimental model, the preoperative irradiation caused a higher incidence of anastomosis dehiscence, detected macroscopically. Also, our results suggest that the best time-interval between irradiation and surgery was 8 weeks, being the healing process more stable and efficient.

\section{References}

1. Beahrs, OH. Complications of colonic surgery. Surg Clin North Am. 1967;47:9838.

2. Curley SA, Allison DC, Smith DE, Doberneck $\mathrm{RC}$. Analysis of techniques and results in 347 consecutive colon anastomoses. Am J Surg. 1988;155:597-601.

3. Fielding LP, Stewart-Brown S, Blesovsky L, Kearney G. Anastomotic integrity after operations for large-bowel cancer: a multicentre study. Br Med J. 1980;281:4114.

4. Goligher JC, Lee PW, Simpkins KC, Lintott DJ. A controlled comparison one- and twolayer techniques of suture for high and low colorectal anastomoses. Br J Surg. 1977;64:609-14.

5. Law W, Chu KW, Ho JWC, Chan CW. Risk factors for anastomotic leakage after low anterior resection with total mesorectal excision. Am J Surg. 2000;179:92-6.

6. Golub R, Golub RW, Cantu Roberto Jr., Stein HD. A multivariate analysis of factors contributing to leakage of intestinal anastomoses. J Am Coll Surg. 1997;184:36472.

7. Makela JT, Kiviniemi H, Laitinen S. Risk factors for anastomotic leakage after leftsided colorectal resection with rectal anastomosis. Dis Colon Rectum. 2003;46:653-60.

8. Akyol AM, McGregor JR, Galloway DJ, Murray GD, George WD. Anastomotic leaks in colorectal cancer surgery: a risk factor for recurrence? Int J Colorectal Dis. 1991;6:179_ 83.

9. Petersen S, Freitag M, Hellmich G, Ludwig K. Anastomotic leakage: impact on local recurrence and survival in surgery of colorectal cancer. Int $\mathbf{J}$ Colorectal Dis. 1998;13:160-3

10. Mantovani M, Leonardi LS, Alcantara FG, Hadler WA. Estudo comparativo entre suturas em plano único e em dois planos no intestino delgado na vigência de isquemia: trabalho experimental no cão. Rev Paul Med. 1976;87:56-63.

11. Jex RK, van Heerden JA, Wolff BG, Ready RL, Ilstrup DM. Gastrointestinal anastomoses. Factors affecting early complications. Ann Surg. 1987; 206:138-41.

12. Pucciarelli S, Toppan P, Friso ML, Fornasiero A, Vieceli G, Marchiori E, Lise M. Preoperative combined radiotherapy and chemotherapy for rectal cancer does not affect early postoperative morbidity and mortality in low anterior resection. Dis Colon Rectum. 1999;42:1276-84.

13. Baffa LP, Garcia RLS, Campos AD, Rocha JJR, Feres O. Efeito da anemia aguda na cicatrização de anastomoses colônicas. Estudo experimental em ratos. Rev Bras Coloproct. 2005;25:24-30.

14. Alves A, Panis Y, Trancart D, Regimbeau JM, Pocard M, Valleur P. Factors associated with clinically significant anastomotic leakage after large bowel resection: multivariate analysis of 707 patients. World J Surg. 2002;26:499-502.

15. Schrock TR, Deveney CW, Dunphy JE. Factor contributing to leakage of colonic anastomoses. Ann Surg. 1973;177:513-8.

16. Gilmour DG, Aitkenhead AR, Hothersall AP, Ledingham IM. The effect of hypovolaemia on colonic blood flow in the dog. Br J Surg. 1980;67:82-4.

17. Sheridan WG, Lowndes RH, Young HL. Tissue oxygen tension as a predictor of colonic anastomotic healing. Dis Colon Rectum. 1987;30:867-71. 
18. Debas HT, Thompson FB. A critical review of colectomy with anastomosis. Surg Gynecol Obstet. 1972;135:747-52.

19. Sousa JB. Estudo da cicatrização em anastomoses no intestino delgado de coelhos tratados com diclofenaco sódico. Ribeirão Preto, 1989. 104p. Tese (Mestrado) - Faculdade de Medicina de Ribeirão Preto, Universidade de São Paulo.

20. Rosemberg D, Nasser A, Behmer OA, Regen JB, Oksman PV, Deutsch CR. Ação da betametasona nas anastomoses intestinais em um e dois planos de sutura com diferentes materiais. Rev. Paul Med. 1976;87:98-106.

21. Martins Jr. A. Cicatrização de anastomoses no intestinais sob efeito da dexametasona: trabalho experimental no intestino delgado do cão. Ribeirão Preto, 1987. 64p. Tese (Mestrado) - Faculdade de Medicina de Ribeirão Preto, Universidade de São Paulo.

22. Alberts JC, Parvaiz A, Moran BJ. Predicting risk and diminishing the consequences of anastomotic dehiscence following rectal resection. Colorectal Dis. 2003;5:478-82.

23. Pakkastie TE, Luukkonen PE, Jarvinen HJ. Anastomotic leakage after anterior resection of the rectum. Eur J Surg.1994;160:293-7.

24. Rullier E, Laurent C, Garrelon JL, Michel P, Saric J, Parneix M. Risk factors for anastomotic leakage after resection of rectal cancer. Br J Surg. 1998;85:355-8.

25. Vignali A, Fazio VW, Lavery IC, Milsom JW, Church JM, Hull TL, Strong SA, Oakley JR. Factors associated with the occurrence of leaks in stapled rectal anastomoses: a review of 1,014 patients. J Am Coll Surg. 1997;185:105-13.

26. Miettinen RP, Laitinen ST, Makela JT, Paakkonen ME. Bowel preparation with oral polyethylene glycol electrolyte solution vs. no preparation in elective open colorectal surgery: prospective, randomized study. Dis Colon Rectum. 2000;43:669-75.

27. Feres O, Monteiro dos Santos Jr JC, Andrade JI. The role of mechanical bowel preparation for colonic resection and anastomosis: an experimental study. Int $\mathbf{J}$ Colorectal Dis. 2001;16:353-6.

28. Saltz LB, Minsky B. Adjuvant therapy of cancers of the colon and rectum. Surg Clin North Am. 2002;82:1035-58. Review.

29. Ajlouni M. The role of radiation therapy in the adjuvant treatment of rectal cancer. Curr Opin Gastroenterol. 2001;17:86-90.

30. Blake DP, Bubrick MP, Kochsiek GG, Feeney DA, Johnston GR, Strom RL, Hitchcock CR. Low anterior anastomotic dehiscence following preoperative irradiation with 6000 rads. Dis Colon Rectum. 1984;27:176-81.

31. Bubrick MP, Rolfsmeyer ES, Schauer RM, Feeney DA, Johnston GR, Strom RL, Hitchcock CR. Effects of high-dose and lowdose preoperative irradiation on low anterior anastomoses in dogs. Dis Colon Rectum. 1982;25:406-15.

32. Ceelen W, El Malt M, Cardon A, Berrevoet F, De Neve W, Pattyn P. Influence of preoperative high-dose radiotherapy on postoperative outcome and colonic anastomotic healing: experimental study in the rat. Dis Colon Rectum. 2001;44:717-21.
33. El-Malt M, Ceelen W, De Meerleer G, Verstraete A, Boterberg T, Van belle S, De Hemptinne B, De Neve W, Pattyn P. Influence of preoperative combined radiochemotherapy on surgical outcome and colonic anastomotic healing: experimental study in the rat. Int J Radiation Oncology Biol Phys. 2001;50:1073-8.

34. Morgenstern L, Sanders G, Wahlstrom E, Yadegar J, Amodeo P. Effect of preoperative irradiation on healing of low colorectal anastomoses. Am J Surg. 1984;147:246-9.

35. François Y, Nemoz CJ, Baulieux J, Vignal J, Grandjean JP, Partensky C, Souquet JC, Adeleine P, Gerard JP. Influence of the interval between preoperative radiation therapy and surgery on downstaging and on the rate of sphincter-sparing surgery for rectal cancer: the Lyon R90-01 randomized trial. J Clin Oncol. 1999;17:2396-402.

36. Stein DE, Mahmoud NN, Anne PR, Rose DG, Isenberg GA, Goldstein SD, Mitchell E, Fry RD. Longer time interval between completion of neoadjuvant chemoradiation and surgical resection does not improve downstaging of rectal carcinoma. Dis Colon Rectum. 2003;46:448-53.

37. Stegemann, H. Stalder, K. Determination of hydroxyproline. Clin Chim Acta. 1967;18:267-73.

38. Medugorac, I. Collagen content in different areas of normal and hypertrophied rat myocardium. Cardiovasc Res. 1980;14:5514.

39. Fleiss JL. Statistical methods for rates and proportions $-2^{\text {nd }}$. Edition, Ed. John Wiley \& Sons, 1981.

40. Dunphy JE. The cut gut. Am J Surg. 1970;119:1-8.

41. Irvin TT. Collagen metabolism in infected colonic anastomoses. Surg Gynecol Obstet. 1976;143:220-4.

42. Oliveira PG. Efeitos da peritonite por Cândida albicans na cicatrização de anastomoses colônicas: estudo experimental em ratos. Ribeirão Preto, 1995. 119p. Tese (Doutorado) - Faculdade de Medicina de Ribeirão Preto, Universidade de São Paulo.

43. Wellwood JM, Jackson BT, Bates TD. Breakdown of small-bowell anastomoses after pelvic radiotherapy. Ann R Coll Surg Engl. 1974;54:306-8.

44. Hopewell JW, Campling D, Calvo W, Reinhold HS, Wilkinson JH, Yeung TK. Vascular irradiation damage: its cellular basis and likely consequences. Br J Cancer Suppl. 1986;7:181-91. Review.

45. Fajardo LF. Morphology of radiation effects on normal tissues. In: Perez CA and Brady LW eds. Principles and practice of radiation oncology. Philadelphia: Lippincott-Raven Publishers, 1997.

46. Hendriks T, Mastboom WJ. Healing of experimental intestinal anastomoses. Parameters for repair. Dis Colon Rectum. 1990;33:891-901.

47. Ravo B. Colorectal anastomotic healing and intracolonic bypass procedure. Surg Clin North Am. 1988;68:1267-94.

48. Wise L, McAlister W, Stein T, Schuck P. Studies on the healing of anastomoses of 
small and large intestines. Surg Gynecol Obstet. 1975;141:190-4.

49. Ballantyne GH. The experimental basis of intestinal suturing. Effect of surgical technique, inflammation, and infection on enteric wound healing. Dis Colon Rectum. 1984;27:61-71.

50. Herrmann JB, Woodward SC, Pulaski EJ. Healing of colonic anastomoses in the rat. Surg Gynecol Obstet. 1964;119:269-75.

51. Kuzu MA, Koksoy C, Akyol FH, Uzal D, Kale T, Demirpence E. Effects of preoperative fractioned irradiation on left colonic anastomoses in the rat. Dis Colon Rectum. 1998;41:370-6.

52. Biert J, Hoogenhout J, Wobbes T, Hendriks T. High-dose preoperative irradiation without detrimental effect on early repair of anastomoses in the colon of the rat. Radiat Res. 1997;147:362-8.

53. De Meerleer G, Pattyn P, Fortan L, De Wever N, Cuvelier C, Van Renterghem K, Berrevoet F, De Neve W. High-dose preoperative radiotherapy does not alter the strength of unilaterally irradiated colon anastomoses in rats. Int J Radiat Oncol Biol Phys. 1999;44:163-70.

54. Savage FJ, Lacombe DL, Boulos PB, Hembry RM. Role of matrix metalloproteinases in healing of colonic anastomosis. Dis Colon Rectum. 1997;40:962-70.

55. Battegay EJ. Angiogenesis: mechanistic insights, neovascular diseases and therapeutic prospects. J Mol Med. 1995;73:333-46.

56. Shweiki D, Itin A, Soffer D, Keshet E. Vascular endothelial growth factor induced by hypoxia may mediate hypoxia-initiated angiogenesis. Nature. 1992;359:843-5.

57. Plate KH, Breier G, Millauer B, Ullrich A, Risau W. Up-regulation of vascular endothelial growth factor and itis cognate receptors in a rat glioma model of tumor angiogenesis. Cancer Res. 1993;53:5822-7.

58. Weiber S, Jiborn H, Zederfeldt B. Preoperative irradiation and colonic healing. Eur J Surg. 1994;160:47-51.

\section{Correspondence:}

Omar Féres

Department of Surgery and Anatomy

Ribeirão Preto Faculty of Medicine, University of São Paulo

Av. Bandeirantes 3900,

14048-900 Ribeirão Preto, SP, Brazil

oferes@fmrp.usp.br

\section{How to cite this article:}

Franca A, Ramalho FS, Zambeli LN, Rocha JJR, Féres O. Effects of preoperative pelvic irradiation on colonic ${ }^{1}$ anastomosis healing. An experimental study in rats. Acta Cir Bras [serial on the Internet], 2008; 23 Suppl 1. Available from URL: http://www.scielo.br/acb.

\section{Comments:}

The manuscript entitled" Effect of preoperative pelvic irradiation on colonic anastomosis. An experimental study in rats" is a well written full paper in English with the addition of a summary in Portuguese. Reading of both versions of the Abstract gives a very good description of the study and the methods used adequately meet the working hypothesis. The morphological, histochemical and biochemical (hydroxyproline) evaluation of the anastomosis healing is efficient. The results, in graphs, are easily understood and the discussion is well argued. The paper is written in good English and excepting the comments on references, it could be published by the journal

\section{Sergio Zucoloto}

Full Professor and Head, Department of Pathology, Ribeirão Preto Faculty of Medicine, University of São Paulo, Brazil.

\section{Comments:}

It is a well conducted experimental study, on a current important subject. Pre-surgical radiotherapy associated or not to chemotherapy for rectal cancer, has been increasingly used in recent years especially for medial and low rectal tumors. As demonstrated in this study, radiotherapy interferes in the cicatricial process. However, the ideal moment after ending radiotherapy and to proceed with surgery, thus reducing post- operatory morbidity is the arguable point. The present study addresses the subject with and adequate " $n$ " and the results shown in graphs and easily understandable were statistically analyzed. Cicatrisation in anastomosis was evaluated by histopathological methods in addition to the biochemical hydroxyproline determination. Adistinguishing factor in this experiment is the immunohistochemical evaluation of anastomosis with the vascular growing factor (VGF) and the determination of both the metalloproteinases and their inhibitors, enzymes acting in the synthesis and degradation of collagen.

\section{Ricardo Luiz Santos Garcia}

MD, Fellow PhD degree, Division of Coloproctology, Department of Surgery and Anatomy, Ribeirão Preto Faculty of Medicine, University of São Paulo, Brazil. 